\title{
CHANGES IN THE FINANCING OF MUNICIPALITIES AND LOCAL GOVERNMENTS OF SELECTED CITIES: POSSIBLE EFFECTS ON DISINTEGRATION PROCESSES AND MUNICIPAL POLICY
}

\section{Pavel Roubínek, Petr Kladivo, Marián Halás, Jaroslav Koutský, Zdeněk Opravil}

\section{Introduction}

There was a significant reduction in the number of municipalities in the Czech Republic in the era of socialism. This was a consequence of the application of the central system of settlement, which was based on Christaller's theory of central places. In connection with the changes after 1989, there was a disintegration of such integrated communities and the situation has since stabilized. A number of small villages were renewed but cities with inhabitants of a hundred thousand (population of these cities oscillates around a hundred thousand inhabitants) did not experience such processes. Due to this fact the big cities in the Czech Republic are typical for their larger size because they also administrate smaller residential units of rural characteristics, often many kilometers from the city centers. These administrative parts of the cities are managed in different ways. In connection with the manifestations of suburbanization during the past twenty years, the transformation of the social structure of the inhabitants in these "suburbs" and changes in rules of municipal budgetary allocation of taxes (hereinafter BAT) there is the question of sustainability and stability of such defined borders of municipalities. The paper presents opinions on the development of the financing system and attempts to analyze the motives of the peripheral parts of selected cities with inhabitants of a hundred thousand to remain part of or separate from these cities. In connection with changes in the BAT made on 1st January 2013, the financial motive can have an important role. The main aim of the paper will be a comparison of the current financial income of these municipalities with previous periods in relation to changes in the BAT and assess the impact of these changes on the potential disintegration processes and municipal politics. The process of urban disintegration and creation of a new municipality is not easy and is provided for in the legal system of the Czech Republic. The paper also gives an overview of this legislation. The authors focus on the cities of Olomouc and Pardubice. The whole study follows on detailed research of the suburban zones and its development in the hinterlands of cities with about 100 thousand inhabitants. Theoretical results are confronted with a real situation in municipalities, the main source of information from practice were structured interviews with representatives of 20 municipalities, mainly mayors.

\section{Theoretical Background}

The financing of local governments defines an important framework for their successful operation. Territorial governments provide a range of services to the population, so it is essential that the system of local government is as efficient as possible [26]. Optimization of the space systems, respectively public finance system in general, and more specifically the distribution of finances and competences between the central (national), regional and local levels are also discussed in the theory of public finance. One of the basic theories of public finance is the theory of fiscal federalism. This theory arose after World War II and began to develop mainly during the 50s-70s of 20th century. It was created for reasons of inefficient allocation of funds for the provision of financial assets in the public sector, which began to show 
a tendency towards strengthening the role of local government, in particular the powers and responsibilities of municipalities in decision making and in the economic sphere. The public sector is in most countries divided into several administrative levels and these levels share the execution of public administration. The consequence of this division is the existence of multi-stage organization of public budgets and the relationships between them. Peková [24] states that the theory of fiscal federalism is based precisely on the existence of multilevel government and the optimal allocation of powers and responsibilities between them. The development of this theory was possible thanks to economists in the Anglo-Saxon countries (Charles Tiebout, Richard Musgrave, Wallace, Oates). Musgrave [20] outlined an alternative attribution of functions to different levels of management. Tiebout [37] had already pointed out "voting with feet" which explained the decision making of inhabitants in a particular region (city or town) according to its actual preferences towards public goods on the one hand and on the other hand according to the willingness to pay local taxes (He actually formulated the socalled fiscal migration hypothesis). Even in the most detailed work on fiscal federalism Oates [22] points out that population mobility helps to increase the effect of decentralization but at the same time it might not be necessary for the actual decentralization of local public goods.

Based on the works of Musgrave and Tiebout [20], [21], [37], [38] we talk about the model of the so called "layered cake". It is the organization of relations within the public sector and public finance. The central government should exercise particular stabilization and fiscal redistribution functions, regional or local government should focus on fiscal power allocation function. In this case it is the horizontal model of fiscal federalism. This is a separation of powers where the central decision-making is connected with decentralized execution of functions. The vertical model of fiscal federalism (or vertical structure of the budget system) can be either in centralized, decentralized or combined form [24]. The second case is a horizontal model of fiscal federalism (horizontal structure of the budget system) which is typical for the financial relations between different levels of government budgets in a horizontal line. Central decision making is accompanied by decentralized exercise of the functions. When the central administration is mostly underdeveloped. The principle of solidarity is followed. Tax policy and tax legislation is uniform and centralized [26].

In recent decades, the Central European countries put emphasis on the issue of fiscal federalism. Especially in the context of the increasing role of local governments and the process of decentralization and deconcentration. In many states there were or still are ongoing reforms of public administration, which led to transfer of certain powers and functions to lower levels of government [18]. In this process, the issue of public finances and public administration often appears as a topic for academic study [4], [19], [25], [34]. In addition to fiscal federalism there are also concepts of fiscal autonomy and fiscal decentralization in the scientific literature (e.g. [3], [7], [9], [13], [31]). These terms cannot be considered synonyms. Fiscal autonomy in general refers to the ability of territorial and administrative units to provide the desired level of income, and subsequently determine how to use it for the benefit of the inhabitants of this unit. It is in fact a subset of fiscal federalism, which addresses a much broader relationships, e.g. in relation to the central level of government. Fiscal decentralization is a process leading to greater fiscal autonomy (transfer of legislative and political powers in planning, decisionmaking and control from the central level to a lower level - closer to the citizen). The fundamental task is to search for the optimal degree of decentralization of the public sector to lower government levels and an increase in the effectiveness and quality in financing its needs. Tanzi [36] distinguishes between fiscal and administrative decentralization. We talk about the fiscal decentralization if the lower administrative units have the powers given by legislature to choose and impose taxes and bear responsibility for their spending activities. Conversely, if the majority of the taxes are levied at the central level and revenues are redistributed to local decentralized administrative units and their spending activities are carried out under the control of the central government, Tanzi [36] speaks about administrative decentralization.

Topics of competences, system settings of governance at the local level are associated with decentralization and fiscal federalism. This is based on the idea that you cannot govern effectively from a single (state) center. 
Partial decentralization of the public sector also helps to increase the intensity of public control over the spending of public funds. The functioning of local administration sometimes uses the term "local state" in the literature. This does not mean full sovereignty typical of state but only the administration and management of local administration units. Linking the two levels can also be called a "dual state" [28]. The theory of local autonomy is also developed by Clark [8], who in this context speaks of two primary principles of local autonomy: power of initiative and power of immunity. Initiative refers to the power to act, to enact own legislation and regulate the activities of private persons. Immunity refers to the power to do without the supervision of higher levels of the state. In the case when a local government has power of initiative and immunity, it is a full local state. If the local government lacks initiative and immunity local authorities are merely an administrative tool of the higher levels of the state.

In the cities and larger towns there is an alternative distribution of management and competence on local (municipal) level to the other two "sub-levels". According to this system Barlow [1] states three basic models of large cities:

a) polycentric model,

b) unitary model,

c) two-stage model.

In a polycentric model there is no directly elected central government (local government) for the entire city. Management is decentralized to local authorities. There is no citywide level management, long term planning and the link to the regional level is problematic. This control method is practically nonexistent in Europe. Unitary model has one central authority which covers the entire city. The main shortcoming here is excessive centralization and the ability to solve partial problems of individual urban areas and their citizens. The two-stage model should combine the advantages of the two previous models, reducing the effects of fragmentation, while maintaining the benefits and the existence of smaller units. Many authors emphasize this model for its greater respect for the values of participation, and the availability of local identity. In the case of the application, there is an important debate on the question of competences which should be kept at the city-wide level and which should be further decentralized (e.g. [2], [14], [30]).
In the Czech Republic the statutory cities should have a seemingly two-stage model management but in fact it is not entirely clear. Only eight of the twenty-six statutory cities have directly elected bodies (local government) at two levels: Prague, Brno, Ostrava, Plzeň, Liberec, Ústí nad Labem, Pardubice and Opava (Tab. 1). Liberec and Opava are also special cases. Liberec has a specific way of managing with only one city district and the rest reports directly to city authorities, Opava has eight local government units in the suburbs of the city, and the city center is managed directly by the city authorities. Other statutory cities have a unitary governance model, where lowerlevel authorities are not directly elected local government. They have limited powers and only an advisory function [11].

Setting the municipal financing rules of budget tax (MFRBT) or setting alternative fiscal autonomy is an important issue for management, control and generally for the development of cities and villages. The dominant revenue from taxes, tax determination, is connected with the determination of the optimal vertical structure of taxation. McLure [17] emphasizes the importance of these issues when decentralizing taxes: Which level of government decides which taxes the government imposes? Which level of government sets the tax base? Which level determines the level of tax rates? Which level manages the level of taxes? In this context there is also important legislation correcting the level of indebtedness of municipalities that are significantly different in each country and in some cases participation of citizens in a referendum may be reflected [29]. Nominal amount of redistribution of finances for municipalities depends apart from setting of parameters described in the paper on the total amount of tax revenues. These can be optimised by the correct setting of tax policy [10]. The enhancement of fiscal union can be helped for instance by activities of local leaders or NGOs, mapped in detail in the contribution of Laboutková [15].

In the Czech Republic, the system of financing of municipalities is important particularly for the outskirts of large cities, which are often affiliated to former independent residential units [12]. Their management and financing may be significantly different depending on whether they are or are not part of the central city. The analysis of this question will also be the subject of this paper. 
2. The Current System of SelfGovernment of Cities with a Hundred Thousand Inhabitants Regard to Olomouc

Already the Act No. 367/1990 Coll., on municipalities (local government) [45] and Act No. 418/1990 Coll., on the capital city of Prague [49], stated that the statutory cities and the capital city of Prague can be divided into self- governing districts as determined by the board of representatives of the statutory city in the state of the city. But there is a discrepancy in the breakdown of statutory towns in the Czech Republic because not all use the opportunity to further breakdown their structure, respectively into two-stage management (i.e. each district has its own council and mayor). This matter is currently in compliance with applicable legislation fully in the competence of individual cities.

\section{Tab. 1: The statutory cities with two stage system of government}

\begin{tabular}{l|l}
\multicolumn{1}{c|}{ City } & \multicolumn{1}{c}{ Type of division } \\
\hline Praha & 22 urban administrative districts (internal division) and 57 city districts \\
\hline Brno & 29 city districts \\
\hline Ostrava & 23 city districts \\
\hline Plzeň & 10 city districts \\
\hline Liberec & 1 city districts, the rest is subject directly to the authorities of the city (35 city parts) \\
\hline Ústí nad Labem & 4 city districts \\
\hline Pardubice & 8 city districts \\
\hline Opava & 8 city parts, the center of the city reports directly to authorities \\
\hline
\end{tabular}

Source: official websites of cities; web CZSO (2013)

Olomouc belongs among autonomously undivided cities with one hundred thousand inhabitants. There are, however, the commissions of city districts which are established and dissolved by Olomouc City Council (hereinafter OCC). These commissions (total 27) have a certain city allocated funds (300 thousand annually) which they manage. Fundamental decisions are taken at the city level (OCC) and the Commission are actually rather an advisory capacity. At the head of each city district commission is the Chairman who is appointed by the Mayor of Olomouc (Statute of the city district commissions 2011) [32].

Based on information obtained during interviews with selected chairmen of city district commission it can be said that this is essentially a voluntary function because reward for its execution is set at $1,900 \mathrm{CZK}$ per month for the President and 500 CZK per month for members of the commission. The Number of members in the city district commission is 5-15, composition reflects and respects the municipal council elections in Olomouc. The problem is a small interest in the membership in the Commissions and the high average age of their members. The Chairmen of city district commission are brought together and managed by municipality workers (Public Relations and Information Department, department of city district commissions). The presidents of the city district commissions should transmit incentives to the department which should address them in the operation of the City Council. However, this cooperation according to the gathered information does not work. In urban areas there are detached workplaces of the municipality, which are regularly visited by a specialized worker. But in the case of some districts (Chomoutov) the worker does not go there regularly and doesn't do anything. The chairmen of city district commissions (mainly peripheral districts) would clearly welcome higher autonomy of city district commissions respectively decentralization of municipal government (the so-called "small City Halls"). The problem in the case of some parts of the cities is the fact that the negotiations with the city are affected by personal relationships and also as to whether a member of the council or 
the city council is a resident of one or another district (own research 2013). Among other cities with hundred thousand inhabitants which are autonomously undivided we can include cities Hradec Králové or České Budějovice that are divided into České Budejovice 1-7 but they are not autonomous.

\section{The Settlement System of the Czech Republic, the Integration and Disintegration of Municipalities in History}

The Settlement system of the Czech Republic is characterized by several specific features. It is primarily a very high density of settlements, their uneven distribution, a high frequency of small rural settlements and the relatively small number of large cities. Additionally, you can find significant regional differences, such as a dense network of small settlements typical of the Czech and Czech-Moravian highlands, while the areas of Moravian and Silesian lowlands typically have larger and more remote settlements [6].

The current form of the settlement system of the Czech Republic is a long lasting result of various historical processes. The number of settlements reached it's historical peak in the High Middle Ages. Then there was a decline in their numbers, especially due to various wars (Hussite wars, the Thirty Years War) or unsatisfactory financial performance of municipalities. The Thirty Years War was an important milestone because after this war there was stabilization in residential structure which has lasted up till the present day.

The term settlement is in geography perceived as an elementary unit of population [16]. Settlements are therefore cities, villages and spatially separated districts of municipalities, etc. no matter what their administrative status whether they are or are not the autonomous municipalities. The average size of municipalities in the the Czech Republic amounts to 1,634 inhabitants [5]. Fragmented population structure is not special within the Central European conditions. The smallest average city population in Europe (1,300 inhabitants) belongs to France [39].

There were many theories concerning the ideal size of the municipality in history. In general, most of them emphasized the increase in the average size of the municipality (due to reduced costs and increased efficiency control).
Many of these theories have become the official development policy instruments of some states. In our environment it was so called central system of settlement proposed in 60 s and 70 s of the last century by a group of Czech urban planners, which became for some time the basis of official policy of territorial development of the former socialist Czechoslovakia.

The Hierarchical system of mainframe sites should have become the framework of settlement systems. These sites should have become focal points of territorial development, services to residents in its vicinity and be objectives of investment. The system distinguished between three respective levels of mainframe sites (centers). Large rural municipalities with 1,500-2,000 inhabitants were chosen as the centers of local importance. In addition to its own population, centers should have provided basic needs for the population of smaller non-mainframe sites in its facilities, including about 3,000-6,000 inhabitants. Rural settlements not included in mainframe sites non-mainframe residental units were divided into two groups: the first consisted of permanent character settlements and the second consisted of other residental units. As suggested by the terminology, maintaining other residental units wasn't expected in the future. Around 1,700 centers of local importance have been identified. A higher degree was formed by centers of the district significance which were fully equipped and offered higher services to the population in the vicinity covering at least 50,000 inhabitants. There were nearly two hundred of them - they were the cities with 30-80 thousand inhabitants. The third and the highest degree consisted of centers of regional significance, which should have provided their residents and residents from the surrounding area the most demanding services. This category included the 20 biggest cities. Centers of the district and regional significance should have received crucial part of the investments.

Despite the fact that these centers should have been means of planned regulation of settlement and for some time actually influenced the spatial distribution of investments, this system was included among projects of utopian character. Gradually, it has been found that it is too schematic and directive and underestimates the significance of the impact of spontaneous and hence unforeseeable development factors whose spatial distribution defied the 
predetermined nomenclature. Despite the regulation settlements which weren't expected to develop developed and vice versa. The system underestimated the developing importance of regional location of settlements, often more important than their population size. Because the central system gradually lost its regulatory function and disappeared from official documents during the 80s [39].

The introduction of the central system of settlement resulted in a drastic reduction of municipalities in our area (administratively). Just between 1970 and 1980 there was a reduction in the number of municipalities by almost 3,000 (7,511 municipalities in 1970 and 4,778 in 1980) [27]. Municipalities were not obviously physically destroyed, but there was an administrative integration. It basically acquired two forms: either the municipalities were merged into a new territorial unit, or were managed (without merging) by another larger municipalities and its national committee. Municipalities therefore existed but failed to meet basic settlement functions and stopped developing [35].

In connection with the changes after 1989, a municipal system was established in 1990 with a guarantee of autonomous selfgovernment administrative unit, municipality. The process of disintegration of municipalities into smaller administrative units was immediate consequence. From 1989, largely in response to the previous compounds, process of division of municipalities spontaneously started and a significant number of municipalities within a relatively short period of time disintegrated into autonomous units. The driving force of this process was an attempt to regain autonomy for the formerly independent municipalities. If in 1990 there were 4,100 independent municipalities in the Czech Republic, in 1994 there were 6,230 (CZSO). On 1st January 2013 there were 6,253 municipalities and approximately 15,000 settlements in the Czech Republic (CZSO). The number of municipalities is therefore about the same as in the midnineties, when a wave of euphoria subsided after 1989. Only eight new municipalities have been established since 2005 (CZSO).

\section{The Legislative Framework for Creation of the New Municipality}

However, in light of recent changes in the context of budgetary allocation of taxes the emergence of new motives for the disintegration of municipalities (this time voluntarily). The question is how the situation will continue to evolve. The entire process of the creation of a new municipality (disjunction) is currently based on Act No. 128/2000 Coll. on municipalities (local government) [41] and Act No. 22/2004 Coll. on local referendum and on a change of certain acts [42], as amended. $\S 21$ paragraph 1 of Act No. 128/2000 Coll. says: "The new municipality may arise by disjunction of municipality part, which must have a separate cadastral territory adjacent to at least two municipalities forming a coherent territorial unit, after the disjunction it will have at least 1,000 inhabitants. The original municipality must also meet the same conditions after the separation of its parts." The current applicable condition of 1,000 citizens means that the efforts of very small parts of cities to become autonomous are not usually successful. But there is a possibility that more local parts join together in the same initiative.

"The disjunction of municipality part must be approved in a local referendum of people living in the territory of the municipality part that wants to become autonomous. In the part of the community that wants to separate, citizens of the municipality establish a preparatory committee." This preparatory committee then proposes a system of local referendum and participates in its preparation and execution and disjunction of municipality. In case of a positive result of a local referendum held in the municipality that wants to separate, a competent regional authority decides on the disjunction of municipality part with delegated powers to the proposal from municipality part (in our case the city from which they want to separate the relevant parts). A Proposal to the disjunction of community and other progressive steps to disintegration are described in Act No. 128/2000 Coll. on municipalities (local government) [41].

\section{The Current Rules of Budgetary Allocation of Taxes in the Czech Republic and Their Possible Impacts}

Tax incomes of municipalities are one of the most important sources of income for municipalities in the Czech Republic and to a large extent affect their financial stability. The 
most significant incomes of municipal budgets are the tax incomes namely tax entrusted and shared. The development budgetary allocation of taxes (BAT) in the Czech Republic can be divided into three periods: 1993-1995, 19962000 and from 2001 to the present. The authors will address the period until 2001.

The funding of cities and municipalities in the Czech Republic is different from other European countries. Larger cities have higher tax revenue per capita (because they perform the functions which are used by the residents of smaller communities). In contrast, small municipalities have lower tax revenue per capita. Tax revenues of municipalities and regions in the Czech Republic are mainly defined by Act No. $243 / 2000$ Coll., On the budgetary allocation of revenues from certain taxes, municipal governments and some state funds (Law on the budgetary allocation of taxes) [43], as amended. Tax incomes of smaller municipalities under the current version of the Act are made up of a proportion of shared taxes, selected tax incomes and the motivational elements. The new law on budgetary tax is aimed at eliminating the causes of unequal income disparities of municipalities (particularly in the case of tax on personal income), removing speculative activities of municipalities in an effort to increase revenue, eliminating instability of municipalities' incomes in different development stages of regulation of taxes by extending the spectrum of taxes, from which municipalities determine the shares of the tax revenue income. The aim of the Act was also the convergence of the dynamics of tax revenues of both segments of public budgets [26]. Another reason for adopting the amendments in BAT was the need to include the financing of new and higher level of local governments (regions). Under the new BAT applicable since 1st January 2001 property taxes and all the proceeds of corporate income tax paid by municipalities remained exclusive tax incomes of municipalities.

Shared tax incomes of municipalities are: tax on personal income from employment, income tax of self-employed persons (only $70 \%$ of tax revenue), the tax on personal income collected by deduction tax, corporate income tax, unless the taxpayer are communities themselves and new tax revenue became municipality's portion of national revenue from value added tax.

The act on budgetary allocation of taxes was during its existence novelized several times, where typically the changes were caused by the need to respond to current issues in public budgets, or a need to change some points that proved problematic during the practice. By 2007, there were 14 sizes of category of municipalities based on population and the coefficient affecting the allocation of the income per capita. At the same time, there were so-called jump effects of the division of finance. The determination of the number of size of categories was based on standard deviations from the average tax revenue from personal income from employment and selfactivity per capita. The individual coefficients of size categories of municipalities should have taken into account the fact that the higher population size of the municipality had a bigger scope of delegated powers [26]. This highly inefficient system of financing of municipalities, which had so called jump character when the calculation coefficients changed significantly with a certain achieved limit of population size, was carrying a number of problems. The most affected were small municipalities of 150 inhabitants, which evolved in an economic pressure on their merging (although this has never been said officially). In the category of municipalities with 200-5,000 inhabitants (the largest group of municipalities) the coefficients had a very modest increase, which contrasts with a significant jump between categories with 50 thousand up to 100 thousand inhabitants (0.8487) and the bigger the cities with 100-150 thousand inhabitants (1.0393). However, in the Czech Republic, there is significant group of cities about the same size and importance, between 90 to 100 thousand inhabitants (České Budějovice, Liberec, H. Králové, Pardubice, Ústí nad Labem, Olomouc), all of which only Olomouc exceeded this level in the long term (last year the population of Olomouc fell under 100 thousand according to data of CZSO). Due to differences in coefficient practically same sized cities, received about $20 \%$ in tax revenue per capita less than Olomouc without the possibility to interfere [26]. Imperfect size of coefficients led in practice to the activities of municipalities, which in order to obtain a higher number of permanent residents paid the "new" people different heights of financial contributions. Examples include cities like Jihlava, which needed to exceed 50 thousand residents or the city of Ústí nad Labem and Kolín [53]. Surrounding municipalities protested strongly against that. People registered 
in cities but continued to live in the surrounding municipalities.

The amendment effective from 2008 (Act No. 377/2007 Coll.) [47] caused removal of the existing senseless jump transitions between different sized categories and (for the purpose of strengthening budgets of the smallest municipalities) added criterior on of the sheer number of inhabitants and the criterior on of the total area of municipality cadastral (both witch $3 \%$ weight). At the same there was a time modification of the existing criteria (the number of inhabitants) which was modified according to coefficient of the size of categories of municipalities ( $94 \%$ weight).

By 2007, Prague had 6.6 times and cities with one hundred thousand inhabitants had 2.5 times more tax revenue per capita compared to the smallest municipalities. After adjusting in 2007/2008, cities with a hundred thousand inhabitants had about 1.6 times higher tax revenue per capita in comparison with the smallest municipalities. From 2008 to 2012 there were four categories of municipalities by population (excluding the jump effects):

- 0-300 inhabitants (coefficient of 1.0000);

- 301 to 5,000 inhabitants (coefficient of 1.0640);

- 5,001-30,000 inhabitants (coefficient of 1.3872);

- 30,001 or more inhabitants (coefficient of 1.7629).

An exception to these rules was formed in the cities of Plzeň, Ostrava, Brno (coefficient 2.5273) and Prague (coefficient 4.2098). A fifty thousand or one hundred thousand threshold with a significant jump did not exist anymore but the bonification based on the coefficients was still quite significant (at the time of its existence until 2007 Olomouc and similarly sized cities on the border of intervals took great care to ensure that the number did not drop below this level, respectively they wanted to avoid separation of some of the parts). Regarding the positive impacts, the smallest municipalities had the largest increases in revenues from shared taxes (population 300), thanks to the newly introduced criterior of the total area of municipality that favors municipalities with low population density. The most unprofitable municipalities were in the categories of 10 to 20 thousand inhabitants and in the category of 20 to 30 thousand inhabitants.
In 2011, an amendment to the budgetary allocation of taxes was presented. It was after the debate and subsequent parametric adjustments adopted and published in the Collection of Laws under No. 295/2012 Coll. as a law amending Act No. 243/2000 Coll. on the budgetary allocation of revenues from certain taxes for municipal authorities and state funds (Act on the budgetary allocation of taxes), as amended, and Act No. 370/2011 Coll. amending Act No. 235/2004 Coll., on value added tax, as amended, and other related laws [44]. Tax revenues are distributed based on the (weights): criteria of cadastral municipalities $(3 \%)$, the sheer number of people in the community $(10 \%)$, multiple successive transitions $(80 \%)$ and the number of children attending schools run by municipalities (7\%). The Amendment Act came into force on 1st January 2013.

The Current categories resulting from the amendment of the Act (without the jump effects):

- 0-50 inhabitants (coefficient of 1.0000);

- 51 to 2,000 inhabitants (coefficient of 1.0700);

- 2,001-30,000 inhabitants (coefficient of 1.1523);

- 30,001 or more inhabitants (coefficient of 1.3663).

Praha (coefficient 4.0641), PIzeň, Ostrava, Brno (coefficient 2.2961)

Figure 1 graphically illustrates the change (in \%) of incomes of municipalities according to their size from BAT since 2013 in regard to the period up to 2008 so it is clear how municipalities in the various categories of population size bettered / worsened off. X-axis is for clarity shown in a logarithmic scale. The vertical lines represent the mentioned "jump effect" abolished since 2008. Figure 2 shows the same changes but between the periods 2008-2012 and since 2013. Both graphs are based on the theoretical assumption that the municipalities were given the same amount of money (thus it captures changes resulting from legislation, particularly changes in the amount of conversion coefficients). Figure 2 also takes into account the fact that according to the conversion coefficients only $80 \%$ of the total funding is recalculated since 1st January 2013. The remaining $20 \%$ is the criterior of the area of municipalities and the number of pupils in primary schools, as mentioned above. The factor of the area and number of pupils was not possible to include in the calculation of the 


\section{Finance}

Fig. 1:

Change in share of revenues of size categories of municipalities from BAT (since 2013 / until 2007)

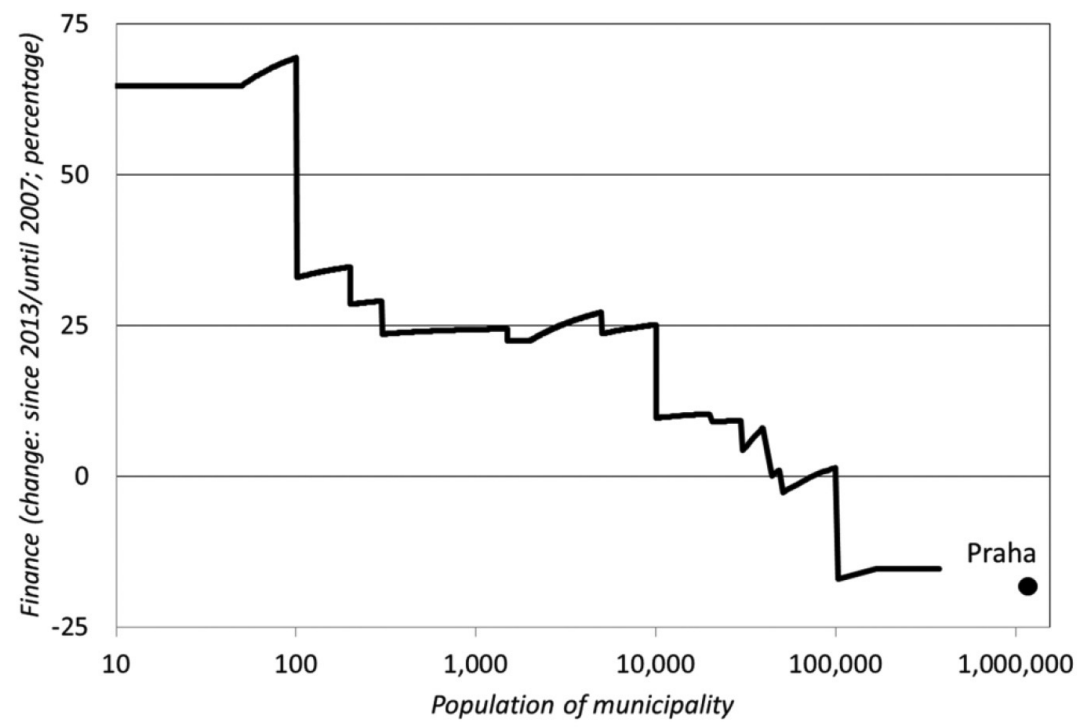

Source: own

Change in share of revenues of size categories of municipalities from BAT (since 2013 / from 2008 to 2012)

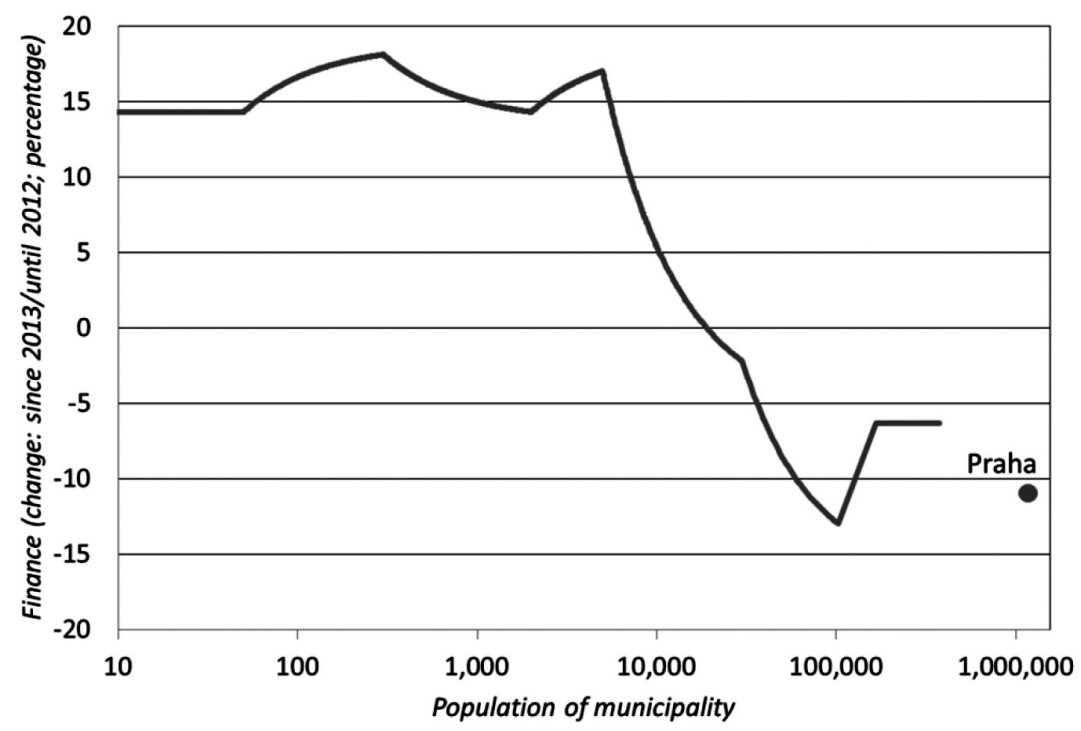


graph as these factors are independent of the number of citizens of municipalities.

The amendment according to the results of the model calculation reinforces small and medium size category of municipalities compared to allocation of taxes under the previous wording of the law on budgetary tax. New conditions helped small municipalities (about 300 inhabitants, up by 18\%), and then the municipalities of moderate size (maximum approximately 5,000 inhabitants, an increase of $17 \%$ ) - generally speaking, all municipalities with approximately 19 thousand inhabitants. On the contrary larger municipality sized categories (from 19 thousand inhabitants and more) were worse off. The greatest loss is recorded in the cities with hundred thousand inhabitants, where there is a loss of about $13 \%$. The Cities of PIzeň, Ostrava and Brno lose according to theoretical calculations about $6 \%$, then Prague with about $11 \%$ loss.

But when comparing the total tax revenues, these changes don't have to be apparent at first glance because these changes can be compensated thanks to the area of municipalities and the number of pupils in primary schools (which helps big cities).

\section{The Impact of Funding Rules on Municipal Policy and Territorial Development (Example of Cities Olomouc and Pardubice)}

Looking at Table 2 the effects of changes in the rules of BAT in municipalities in the suburban area of Olomouc (definition according Halás, Roubínek, Kladivo) [12] and the city itself are apparent. In the case of Olomouc there was reduction of conversion constants by 0.3331 . Though nominal value of shared tax revenue for 2013 is higher (CZK 948.5 million) compared to 2012 (945.9), hundredthousand cities actually have less money at their disposal (see chart. 2) due to the larger volume of allocations, inflation, etc. Previously criticized separate calculation for the largest cities remained unchanged, confirming the continuing large gap in income per capita in Olomouc and Plzeň that in fact are comparable in hierarchical and spatial range of the Czech Republic. According to the fig. 2 revenues of Olomouc and PIzeň declined but, paradoxically, there was a deepening of differences between cities with a hundred thousand inhabitants and Plzeň.

\begin{tabular}{|c|c|c|c|c|c|c|c|c|}
\hline \multirow[b]{3}{*}{ Number } & \multicolumn{8}{|c|}{$\begin{array}{l}\text { Tax revenues of per capita in Olomouc and selected (depending on size) } \\
\text { municipalities from surrounding area (part 1) }\end{array}$} \\
\hline & \multirow[b]{2}{*}{$\begin{array}{l}\text { Municipality } \\
\text { name }\end{array}$} & \multirow[b]{2}{*}{$\begin{array}{l}\text { Population } \\
\text { 2012-01-01 }\end{array}$} & \multicolumn{3}{|c|}{ BAT until 2012-12-31 } & \multicolumn{3}{|c|}{ BAT since 2013-01-01 } \\
\hline & & & Constant $k$ & $\begin{array}{c}\text { Shared } \\
\text { tax incomes } \\
\text { (in hundreds } \\
\text { CZK) }\end{array}$ & $\begin{array}{c}\text { Revenue } \\
\text { per capita } \\
\text { (in thousands } \\
\text { CZK) }\end{array}$ & Constant $k$ & $\begin{array}{c}\text { Shared } \\
\text { tax incomes } \\
\text { (in hundreds } \\
\text { CZK) }\end{array}$ & $\begin{array}{l}\text { Revenue } \\
\text { per capita } \\
\text { (in thousands } \\
\text { CZK) }\end{array}$ \\
\hline 1 & Olomouc & 99,529 & 1.6332 & 945,938 & 9.5 & 1.3001 & 948,498 & 9.5 \\
\hline 2 & $\begin{array}{l}\text { Velká } \\
\text { Bystríice }\end{array}$ & 3,062 & 1.0577 & 19,510 & 6.4 & 1.0974 & 27,232 & 8.9 \\
\hline 3 & Velký Týnec & 2,638 & 1.0567 & 17,350 & 6.6 & 1.0886 & 23,594 & 8.9 \\
\hline 4 & Grygov & 1,468 & 1.0509 & 9,661 & 6.6 & 1.0676 & 12,118 & 8.3 \\
\hline 5 & Práslavice & 1,363 & 1.0499 & 8,764 & 6.4 & 1.0674 & 11,026 & 8.1 \\
\hline 6 & Příkazy & 1,229 & 1.0484 & 8,217 & 6.7 & 1.0672 & 10,420 & 8.5 \\
\hline 7 & $\begin{array}{l}\text { Kožušany- } \\
\text {-Tážaly }\end{array}$ & 852 & 1.0415 & 5,513 & 6.5 & 1.0659 & 6,946 & 8.2 \\
\hline 8 & Blatec & 622 & 1.0331 & 4,084 & 6.6 & 1.0644 & 5,220 & 8.4 \\
\hline 9 & Bukovany & 600 & 1.0320 & 3,796 & 6.3 & 1.0642 & 4,739 & 7.9 \\
\hline 10 & Tovéŕ & 581 & 1.0310 & 3,628 & 6.2 & 1.0640 & 4,538 & 7.8 \\
\hline
\end{tabular}




\begin{tabular}{|c|c|c|c|c|c|c|c|c|}
\hline \multicolumn{9}{|c|}{ Tab. 2: } \\
\hline \multirow[b]{2}{*}{ Number } & \multirow[b]{2}{*}{$\begin{array}{c}\text { Municipality } \\
\text { name }\end{array}$} & \multirow[b]{2}{*}{$\begin{array}{l}\text { Population } \\
\text { 2012-01-01 }\end{array}$} & \multicolumn{3}{|c|}{ BAT until 2012-12-31 } & \multicolumn{3}{|c|}{ BAT since 2013-01-01 } \\
\hline & & & Constant $k$ & $\begin{array}{c}\text { Shared } \\
\text { tax incomes } \\
\text { (in hundreds } \\
\text { CZK) }\end{array}$ & \begin{tabular}{|c} 
Revenue \\
per capita \\
(in thousands \\
CZK)
\end{tabular} & Constant $k$ & $\begin{array}{c}\text { Shared } \\
\text { tax incomes } \\
\text { (in hundreds } \\
\text { CZK) } \\
\end{array}$ & $\begin{array}{c}\begin{array}{c}\text { Revenue } \\
\text { per capita } \\
\text { (in thousands } \\
\text { CZK) }\end{array} \\
\end{array}$ \\
\hline 11 & Ústín & 401 & 1.0161 & 2,601 & 6.5 & 1.0613 & 3,357 & 8.4 \\
\hline 12 & Svésedlice & 190 & 1.0000 & 1,256 & 6.6 & 1.0516 & 1,521 & 8.0 \\
\hline
\end{tabular}

Note: $\mathrm{k}$ is a constant, the resulting multiples are conversion by precise definitions of the regulations using the population of the municipalities to 1st January 2012. BAT revenues for 2013 are theoretical assumption.

Source: Act No 295/2012 Coll., Act No. 243/2000 Coll. as amended by Act No. 377/2007 [43], [44], [47], a new calculation of tax assignment for the Olomouc Region, available at www http://www.kr-olomoucky.cz/rozpocet-olomouckeho-kraje-cl-105.html

As already mentioned, in connection with the adoption of amendments to the rules of BAT there was reduction in differences in per capita incomes of cities and the municipalities in their suburban areas. The latest state is evident from table 2. In the case Olomouc and some other cities with a hundred thousand inhabitants some parts of the cities don't actually have (if they are organized by their authorities) opportunity to intervene in the city's management and direction of future development in the settlement unit. Although there is such a possibility in the case of Pardubice there are however appearing some expressions of discontent. Individual municipalities have, through their local councils, more freedom in terms of management and manage their own assets. In addition separate municipalities benefited to some extent from the recent amendments in the rules of BAT. However, a separate municipality, on the other hand, has a higher degree of responsibility.

In the case of many compact cities their suburbs are, in fact, settlements of rural character separated by built-up areas in the administrative city limits. Individual municipalities with a high degree of interaction with the city are in fact morphologically very similar to the rural parts of the city. Both groups show high rate of suburbanization and links to their own compact city, although suburban processes across the administrative border city of Olomouc are more intense [12]. Difference thus lies mainly in the status of these settlements. It naturally has its impacts, especially in the financing and also in management. In this context (and due to recent changes in the rules of BAT) it is meaningful to compare the advantages and disadvantages of the status of separate municipalities, respectively city districts.

From the financial point of view, it seems that for the settlements in the vicinity of compact cities it is better (although less than before) to be an integral part of the city (own research). However, the question remains, what is the actual amount of funds going from city treasury to invest in specific urban areas. For cities with multi-stage system of government it is ascertainable (Pardubice), but for cities, which are more or less controlled only the central town hall, it is very difficult to find out (Olomouc).

\section{a) Olomouc}

The advantage for the city districts is, among other things provision of waste collection, road maintenance, public lighting, green areas, etc. by technical services of the cities. These items are for separate municipalities, a considerable financial burden. Furthermore, the technical and financial background of the city is an indisputable advantage when implementing specific projects (e.g. construction of sewers in the city district Olomouc-Radíkov, which cost 73 million CZK, implemented in 2006-2008, which was paid by the city of Olomouc, would be for Radíkov as a separate municipality with a few hundred inhabitants from their own budgets very difficult to implement). The question is also a success in obtaining grants from European or other funds, where status of autonomous municipality respectively the city district may play a role. 
Within the city of Olomouc and its suburban hinterland authors implemented a series of structured interviews with local players, especially the mayors and chairmen of the commissions of the city district (CCD). Total number of interviews and their structure was as follows - 18 structured interviews with mayors of municipalities in the suburban zone (including two city parts outside of Olomouc compact city) and two representatives of the affected communities were managed. All interviews were realized in the period from May to July 2013 , the biggest problem was to find the intersection between free time of researchers and respondents. During the realization of interview did not appear any other problems, because the respondents received research questions in advance.

As part of this research, among others, matters relating to the possibility of separation from the city Olomouc or vice versa were identified. Chairmen of CCD in general voted for independence from Olomouc (They consider that independent municipalities would be better off both financially and through options of self-government). But it's individual and it would account only for the larger districts (e.g. Chomoutov, Droždín) with more than 1,000 inhabitants. In the case of smaller districts (Radíkov, Nedvězí) there would have to be a joint activity of more of them to exceed the limit one thousand. In general it can be said that at present there is not any activity for the separation in any of the city districts.

The mayors of municipalities in suburban zones of Olomouc clearly prefer the independence of their municipalities. An example might be Bukovany where the mayor contrasts his municipality with the neighboring Droždín (part of the city of Olomouc).the Chairman of local CCD is allegedly unable to enforce anything. He must deal with each department of the Magistrate separately, has no powers and doesn't have any significant financial resources. But for Droždín it is an unsolvable situation, because it is a road junction with Svatý Kopeček (also part of town), which will never be autonomous, because they would not be able to finance all activities related to tourism such as $-\mathrm{ZOO}$ etc. Striving for independence of Droždín therefore has no sense because the city Olomouc would not be territorially compact, which on the other hand does not apply to all statutory cities.
In addition, in some city districts objective obstacles arise before efforts for the separation (e.g. the above-mentioned drainage). In the case of the city district Chomoutov there is transport of sewage to the sewage treatment plant in Olomouc. In the case of separation there would be need to build its own sewage treatment plant. In addition, there always has to be a group of active people who would take the initiative for the separation, which is a problem in city districts, because there is no tradition of representatives.

\section{b) Pardubice}

Unlike the above-mentioned system of municipal government in the city of Olomouc, Pardubice has decentralized municipal authorities and there are so-called "small town halls." Thanks to last year's changes to the rules of BAT an initiative of residents for separation arose and it lead to the separation of a peripheral part of the city, the circuit Pardubice VI, which includes the local parts of Lány na Důlku, Opočínek, Popkovice, Staré Čívice and Svítkov. This locality is situated in the eastern part of the city. Within the city district preparatory committee was set up in order to create a local referendum on separation in September 2012. In this context, website was launched [23]. It serves as a platform for that initiative. Although the authors of initiative for separation do not dispute former benefits of integrating of municipalities to the city of Pardubice (construction of water mains, sewers, playgrounds, public transport accessibility, winter and summer maintenance), they point to the fact that in 2011 there was removal of certain powers of the city districts, cuts in funding maintenance and repair or that local issues are not decided by the elected representatives of the city district, but by councilors from city Hall.

The main strengths of the forthcoming separation are issues of self-government (there aren't enough people in the municipal council living in the periphery of Pardubice $\mathrm{VI}$ ), as well as better access to services and the ability to better influence the course of municipalities by citizens. Furthermore it is a supposedly better relationship between municipality and its inhabitants (change of status of residence: peripheral city district vs. single municipality). It is important from a financial standpoint, that in the case of Pardubice VI, the district does not receive any funds from the city that it should 
have available as a separate municipality. The budget of the city district finances repairs and maintenance of roads, pavements and green. Large investments (such as construction of sewer system, reconstruction of roads, etc.) are funded from the city budget. For this reason, the city district every year calls for the allocation of money for these investments almost every quarter but in most cases unsuccessfully.

In addition, the city of Pardubice has no rules for the allocation of investment that would ensure balanced development of all parts of the city. Priorities are therefore investment in the city center and the quality of living conditions rises in peripheral parts only very slowly [23]. In the case of the separation the new community would have (under the current rules BAT) after the inclusion of tax and other revenues budget of about 63 million CZK which, according to calculations would covers the needs of communities by a large margin, including the costs of maintenance of existing public transport connections, the cost of waste disposal, lighting, summer and winter maintenance, operation of educational facilities and municipal police. The Population of the new municipality would be about 5,500 . Other benefits were seen in matters of property tax, the possibility to apply individually for grants and subsidies, the possibility to act independently with large firms and the possibility of their own rules within the admission of children to kindergartens.

In the district of Pardubice VI the preparatory committee had received a sufficient number of votes required to hold a referendum (about one fifth were for), but this will not take place and the efforts on the separation has so far been postponed. There are several reasons. There is a rivalry between residents of the local parts of the city district, its role allegedly played argumentation of representatives of the city of Pardubice. In addition, city officials want to leave the future of the layout of the city for people to decide. Members of the Preparatory Committee, therefore, decided to wait for the results of referendum, because if the current preparatory committee announced a referendum that would not end positively, the possibility of holding a referendum on independence would be postponed for the next two years.

\section{Conclusion}

Most of the cities with a hundred thousand inhabitants in the Czech Republic include not only their own "real" clearly graspable urban space but also units of suburban and rural character, morphologically separated from typical urban development. These are largely the municipalities integrated in 70s and $80 \mathrm{~s}$ of the 20th century in connection with the central system of settlements. This definition does not need to undergo criticism. Locations lying in the discontinuous urban area of cities have the option of alternatives: remain as part of the city or separation if they deem it convenient. Changes realized in the budgetary allocation of taxes, which strengthened to some extent smaller municipalities and the actual malfunction of multi-stage control system in some cities may play a role in the future. Some civil initiatives have already appeared (Pardubice). In addition, cities are no longer motivated to overcome some limit at all costs (for example hundred thousand inhabitants) as the jump effects were removed and losses in the order of several hundred inhabitants are not that important in the case of separation of some municipal districts. However, losses in the order of several thousand people would affect large cities significantly. It should be borne in mind that although the city is losing part of the funding it also saves because some mandatory spending and investments in separated urban areas (city districts) wouldn't be needed.

To determine whether and to what extent the new conditions of BAT valid from the beginning of 2013 will affect the disintegration processes related to towns and rural settlements will be shown in the development in the coming years. The results of structured interviews with mayors of municipalities in the immediate hinterland of cities with a hundred thousand inhabitants, and representatives of non-autonomous city districts show that it may be a significant motivating factor. But there are several others factors affecting these issues. For example the tradition of local government in new potential municipalities (interrupted by integration in the second half of the 20th century), interest of sufficient population (referendum on separation), facilities of the relevant parts of and theoretical minimum burden on the budget of future independent municipality (e.g., infrastructure projects, etc.), etc. The possibility to manage its own budget, decision-making on the development of the municipality or better management are important motives but they also bring many pitfalls. Among the arguments 
supporting the disintegration of parts of large cities can be included an increase in financial income of mainly small municipalities from BAT and whether these potentially autonomous municipalities count (or not count) with the implementation of major investment projects. These can make a significant burden for individual municipalities and are often realizable only in the larger city budget. Among the arguments against the creation of new municipalities we also count weaker awareness of new BAT and its practical implications on government municipalities.

On specific cases, such as the city of Olomouc, as we have often mentioned, certain disadvantages of central city management with minimal self-government tools can be detected. These smaller municipalities, respective association of their representatives, commissioners, have the status of advisory only, without the possibility to influence the distribution of investments in the city and lobbying for their part associated with the potential development. Thinking about the potential autonomy of city districts is often a politically unsolvable question, although our survey showed that is has support among the general public.

This work was supported by the Grant Agency of the Czech Republic under project Urban and suburban quality of life: a geographical perspective [number P404/11/1811] and by European Social Fund and the state budget of the Czech Republic under project: The enhancement of creation of excellent research teams and intersectoral mobility at Palacký University Olomouc II [number CZ.1.07/2.3.00/30.0041].

\section{References}

[1] BARLOW, M. Alternative structures of government in metropolitan areas. In: BARLOW, M., DOSTÁL, P., HAMPL, M. (Eds.). Development and Administration of Prague. Amsterdam: Universiteit van Amsterdam, Instituut voor Sociale Geografie,1994. pp 125138. ISBN 9069930862.

[2] BENNETT, R. J. (Ed.). Local government and market decentralisation: Experiences in industrialised, developing and former eastern bloc countries. Tokyo: United Nations University Press, 1994. ISBN 9280808346.

[3] BOADWAY, R., SHAH, A. Fiscal federalism: Principles and practice of multiordergovernance.
Cambridge: Cambridge University Press, 2009. ISBN 978-0521732116.

[4] BUČEK, J., BORÁROSOVÁ, Z., SOPKULIAK, A. Miestne financie a miestny ekonomický rozvoj. Bratislava: Geografika, 2010. ISBN 97880-89317-12-7.

[5] COLLECTIVE OF CZECH STATISTICAL OFFICE. Malý lexikon obcí České republiky. Praha: Český statistický úrad, 2004. ISBN 80250-0893-2.

[6] COLLECTIVE OF CZECH STATISTICAL OFFICE. Rozmístění a koncentrace obyvatelstva České republiky. Velikostní struktura obcí. Praha: Český statistický úrad, 2004. ISBN 80250-0810-X.

[7] CHAPMAN, J. I. Local government autonomy and fiscal stress: The case of California counties. State\&Local Government Review. 2003, Vol. 35, Iss. 1, pp. 15-25. ISSN 0160-323X.

[8]CLARK, G.L.Atheoryoflocalautonomy.Annals of the Association of American Geographers. 1984, Vol. 74, Iss. 2, pp. 195-208. ISSN 14678306. doi:10.1111/j.1467-8306.1984.tb01448.x. [9] EBEL, R. D., YILMAZ, S. On the measurement and impact of fiscal decentralisation. World Bank Policy Research Working Paper, No. 2809. Washington: The World Bank, 2002.

[10] HÁJEK, L. The Czech Republic's tax policy in international comparison. E+M Ekonomie a Management. 2003, Special Issue, pp 6-11. ISSN 1212-3609.

[11] HALÁS, M., KLADIVO, P., ROUBÍNEK, P. Koncept kompaktního města: příspěvek k výzkumu a správě. In: XVI. mezinárodní kolokvium o regionálních vědách. Brno: Masarykova univerzita, 2013. pp. 140-146. ISBN 978-80-210-6257-3. doi:10.5817/CZ.MUNI. P210-6257-2013-16.

[12] HALÁS, M., ROUBÍNEK, P., KLADIVO, P. Urbánní a suburbánní prostor Olomouce: teoretické prístupy, vymezení, typologie. Geografický časopis / Geographical Journal. 2012, Vol. 64, Iss. 4, pp. 289-310. ISSN 00167193.

[13] JOHNSON, R. W., MINIS, H. P. $K$ demokratickej decentralizácii. Bratislava: RTI - Centrum pre medzinárodný rozvoj, 1996. [14] KEEN, M., MARCHAND, M. Fiscal competition and the pattern of public spending. Journal of Public Economics. 1997, Vol. 66, Iss. 1, pp. 33-53. ISSN 0047-2727. doi:10.1016/ S0047-2727(97)00035-2.

[15] LABOUTKOVÁ, Š. The establishment of NGOs as one growing part of developing 
interest groups in the Czech Republic. E+M Ekonomie a Management. 2009, Vol. 12, Iss. 1, pp. 14-30. ISSN 1212-3609.

[16] MATES, P., WOKOUN, R. Malá encyklopedie regionalistiky a veřejné správy. Praha: Prospektrum, 2001. ISBN 80-7175-100-6.

[17] McLURE, C. E. The tax assignment problem: Ruminations on how theory and practice depend on history. National Tax Journal. 2001, Vol. 54, Iss. 2, pp. 339-363. ISSN 0028-0283.

[18] MORAND-DEVILLER, J. Cours de droit administratif: cours, thèmes de réflexion, commentaires d'arrêt avec corrigés. 12th edition. Paris: Montchrestien, 2011. ISBN 9782707617286.

[19] MOTEK, P. Gospodarka finansowa samorządu terytorialnego w województwie wielkopolskim. Poznań: Bogucki Wydawnictwo Naukowe, 2006. ISBN 978-8360247648.

[20] MUSGRAVE, R. A. The Theory of Public Finance. New York: McGraw Hill, 1959. OCLC 243503.

[21] MUSGRAVE, R. A. Fiscal systems. New Haven and London: Yale University Press, 1969. OCLC 186571462.

[22] OATES, W. E. Fiscal federalism. New York, Harcourt: Brace and Jovanovich, 1972. ISBN 978-0155274525.

[23] OSAMOSTATNĚNÍ. Nová obec [online]. @ 2013 [cit. 2013-09-15]. Available from: http:// www.novaobec.cz.

[24] PEKOVÁ, J. Hospodaření a finance územní samosprávy. 1st ed. Praha: Management Press, 2004. ISBN 80-7261-086-4.

[25] PÉTERI, G., LADOS, M. Local property taxation in Hungary. In: McCLUSKEY, W. J. (Ed.). Comparative property tax systems: An international comparative review. Aldershot: Ashgate, 1999. pp. 419-439. ISBN 9781859725177.

[26] PROVAZNÍKOVÁ, R. Financování měst, obcí a regionů: teorie a praxe. 2nd ed. Praha: Grada, 2009. ISBN 978-80-247-2789-9.

[27] RŮŽKOVÁ, J., ŠKRABAL, J. Historický lexikon obcí České republiky 1869-2005 (I. díl). Praha: Český statistický úřad, 2006. ISBN 80250-1310-3.

[28] SAUNDERS, P. Rethinking local politics. In: BODDY, M., FUDGE, C. (Eds.). Local socialism? Labour councils and new left alternatives. London: Macmillan, 1984. pp 22-48. ISBN 9780333351857.

[29] SCHALTEGGER, C. A., TORGLER, B. Government accountability and fiscal discipline:
A panel analysis with Swiss data. Journal of Public Economics. 2007, Vol. 91, Iss. 1, pp. 117-140. ISSN 0047-2727. doi:10.1016/j. jpubeco.2006.07.003.

[30] SHARPE, L. J. (Ed.). The government of World cities: The future of the metro model. New York: Wiley, 1995. ISBN 978-0471949824.

[31] SOPKLULIAK, A. Fiškálna autonómia miestnej samosprávy a jej výskum $v$ geografii. Acta Geographica Univesitatis Comenianae. 2012, Vol. 56, Iss. 2, pp. 215-236. ISSN 13386034.

[32] STATUTÁRNÍ MĚSTO OLOMOUCOFICIÁLNÍ INFORMAČNÍ PORTÁL. Statut komisí městských částí [online]. (c) 2011 [cit. 2013-09-15]. Available from:

http://www.olomouc.eu/administrace/ repository/gallery/articles/10_/10122/statut-ajednaci-rad-kmc-olomouc-20110405.cs.doc.

[33] SVOBODA, I., SCHELLE, K. Základy organizace veřejné správy. 2nd ed. Ostrava: KeyPublishing, 2007. ISBN 978-80-87071-22-9. [34] SWIANIEWICZ, P. Finanse lokalne: teoria i praktyka. Warszawa: Municipium, 2004. ISBN 978-8386691920.

[35] ŠAŠıNKA, P. Malé obce v České republice (s důrazem na historické souvislosti 20. století narušujicí jejich přirozený vývoj). Diplomová práce. 2011, Brno, Masarykova univerzita.

[36] TANZI, V. Fiscal Federalism and Decentralision: A review of Some Efficiency and Macroeconomic Aspect. In: The World Bank Research Observer, 1995, pp. 295-316.

[37] TIEBOUT, C. M. A pure theory of local expenditures. Journal of political economy. 1956, Vol. 64, Iss. 5, pp. 416-424. ISSN 00223808.

[38] TIEBOUT, C. M. An economic theory of fiscal decentralization. In: Public finances: needs, sources and utilization. Princeton University Press, 1961. pp 79-96. OCLC 318228798.

[39] VAJDOVÁ, Z., ČERMÁK, D., ILLNER, M. Autonomie a spolupráce: důsledky ustavení obecního zrízení v roce 1990. Sociologické studie (2). Praha: Sociologický ústav AV ČR, v.v.i., 2006. ISBN 80-7330-086-9.

[40] ZÁKON č. 1/2005 Sb. kterým se mění zákon č. 243/2000 Sb., o rozpočtovém určení výnosů některých daní územním samosprávným celkům a některým státním fondům (zákon o rozpočtovém určení daní), ve znění pozdějších předpisư, a některé další zákony.

[41] ZÁKON č. 128/2000 Sb. o obcích (obecní zrízení). 
[42] ZÁKON č. 22/2004 Sb. o místním referendu a o změně některých zákonů.

[43] ZÁKON č. 243/2000 Sb. o rozpočtovém určení výnosů některých daní územním samosprávným celkům a některým státním fondům (zákon o rozpočtovém určení daní).

[44] ZÁKON č. 295/2012 Sb. kterým se mění zákon č. 243/2000 Sb., o rozpočtovém určení výnosů některých daní územním samosprávným celkům a některým státním fondům (zákon o rozpočtovém určení daní), ve znění pozdějších předpisů, a zákon č. 370/2011 Sb., kterým se mění zákon č. 235/2004 Sb., o dani z přidané hodnoty, ve znění pozdějších předpisů, a další související zákony.

[45] ZÁKON č. 367/1990 Sb. České národní rady o obcích (obecní zřízení).

[46] ZÁKON č. 370/2011 Sb. kterým se mění zákon č. 235/2004 Sb., o dani z přidané hodnoty, ve znění pozdějších předpisů, a další související zákony.

[47] ZÁKON č. 377/2007 Sb. kterým se mění zákon č. 243/2000 Sb., o rozpočtovém určení výnosu některých daní územním samosprávným celkům a některým státním fondům (zákon o rozpočtovém určení daní), ve znění pozdějších predpisů.

[48] ZÁKON č. 387/2004 Sb. o změnách hranic krajů a o změně zákona č. 243/2000 Sb., o rozpočtovém určení výnosů některých daní územním samosprávným celkům a některým státním fondům (zákon o rozpočtovém určení daní), ve znění pozdějších předpisů, a zákona č. 314/2002 Sb., o stanovení obcí s pověřeným obecním úřadem a stanovení obcí s rozšířenou působností, a zákona č. 131/2000 Sb., o hlavním městě Praze, ve znění pozdějších předpisů.

[49] ZÁKON č. 418/1990 Sb. České národní rady o hlavním městě Praze.

[50] ZÁKON č. 483/2001 Sb. kterým se mění zákon č. 243/2000 Sb., o rozpočtovém určení výnosů některých daní územním samosprávným celkům a některým státním fondům (zákon o rozpočtovém určení daní), ve znění zákona č. 492/2000 Sb., zákon č. 586/1992 Sb., o daních z př́immů, ve znění pozdějších předpisů, a zákon č. 338/1992 Sb., o dani z nemovitostí, ve znění pozdějších předpisů.
[51] ZÁKON č. 492/2000 Sb. kterým se mění zákon č. 586/1992 Sb., o daních z př́ijmů, ve znění pozdějších předpisů, a některé další zákony.

[52] ZÁKON č. 500/2012 Sb. o změně daňových, pojistných a dalších zákonů $v$ souvislosti se snižováním schodků veřejných rozpočtů.

[53] ŽAMBOCHOVÁ, M. A Statistical Analysis of the Support for Small Business as a Solution for Unemployment in the Usti nad Labem Region. Proceedings of the 11th International Conference Liberec Economic Forum. 2013. Liberec: Technická univerzita v Liberci, 2013. pp. 642-651. ISBN 978-80-7372-953-0.

\author{
Mgr. Pavel Roubínek \\ University of Ostrava \\ Faculty of Science \\ Department of Human Geography \\ and Regional Development \\ pavel.roubinek@upol.cz \\ Mgr. Petr Kladivo, Ph.D. \\ Palacký University Olomouc \\ Faculty of Science \\ Department of Geography \\ petr.kladivo@upol.cz
}

doc. RNDr. Marián Halás, Ph.D.

Palacký University Olomouc

Faculty of Science

Department of Geography

marian.halas@upol.cz

RNDr. Jaroslav Koutský, Ph.D.

J. E. Purkyne University in Usti nad Labem

Faculty of Social and Economic Studies

Department of Regional

and Local Development

jaroslav.koutsky@ujep.cz

Mgr. Zdeněk Opravil

University of Ostrava

Faculty of Science

Department of Human Geography and Regional Development

z.opravil@seznam.cz 


\title{
Abstract
}

\section{CHANGES IN THE FINANCING OF MUNICIPALITIES AND LOCAL GOVERNMENTS OF SELECTED CITIES: POSSIBLE EFFECTS ON DISINTEGRATION PROCESSES AND MUNICIPAL POLICY}

\author{
Pavel Roubínek, Petr Kladivo, Marián Halás, Jaroslav Koutský, Zdeněk Opravil
}

There was significant reduction in number of municipalities in the Czech Republic in the era of socialism. This is a consequence of the application of the central system of settlement, which was based on Christaller's theory of central places. In connection with the changes after 1989, there was disintegration of such integrated communities and the situation has stabilized. Number of small villages were renewed but cities with hundred thousand inhabitants (population of these cities oscillates around hundred thousand inhabitants) did not experience such process. Due to this fact the big cities in the Czech Republic are typical for their larger size because they also administrate smaller residential units of rural character, often many kilometers from the city centers. These administrative parts of the cities are managed in different ways. In connection with the manifestations of suburbanization during the past twenty years, the transformation of the social structure of the inhabitants in these "suburbs" and changes in rules of municipal budgetary allocation of taxes (hereinafter BAT) there is the question of sustainability and stability of thus defined borders of municipalities. The paper presents opinions on the development of financing system and attempts to analyze the motives of the peripheral parts of selected cities with hundred thousand inhabitants to remain part or separate from these cities. In connection with changes in the BAT made on 1st January 2013, the financial motive can have an important role. The main aim of the paper will be a comparison of the current financial income of these municipalities with previous periods in relation to changes in the BAT and assess the impact of these changes on the potential disintegration processes and municipal politics. Process of urban disintegration and creation of a new municipality is not easy and is provided for in the legal system of the Czech Republic. The paper also gives an overview of this legislation. Authors focus on the cities of Olomouc and Pardubice.

Key Words: Finance, municipalities, budgetary allocation of taxes, fiscal federalism.

JEL Classification: H72, H77, R51.

DOI: 10.15240/tul/001/2015-1-011 